\title{
The Voltage-Dependent, Slow Inward Current Induced by the Neuropeptide FMRFamide in Aplysia Neuron R14
}

\author{
Mitsuyuki Ichinose ${ }^{a}$ and David J. McAdoo \\ Marine Biomedical Institute and Department of Human Biological Chemistry and Genetics, University of Texas Medical \\ Branch, Galveston, Texas 77550
}

The effects of the peptide FMRFamide (Phe-Met-Arg-Phe$\mathrm{NH}_{2}$ ) on the soma of neuron $\mathrm{R} 14$ in the abdominal ganglion of Aplysia californica and A. brasiliana were characterized. Pressure-ejected FMRFamide caused 3 types of responses, (1) a fast outward current (duration, $<30 \mathrm{sec}$ ), (2) a fast inward current (duration, $<20 \mathrm{sec}$ ), and (3) a slow inward current (peak at 0.5-1 min; duration, 2-3 min). The slow inward current, the chief object of this study, arises from a voltage-dependent conductance increase. The FMRFamideelicited slow inward current is largest between $-40 \mathrm{mV}$ and $-20 \mathrm{mV}$, the region of a negative slope resistance in the normal current-voltage relationship for $R 14$. The slow FMRFamide-induced inward current is largely carried by $\mathrm{Na}^{+}$. This current is independent of external $\left[\mathrm{K}^{+}\right]$but depends inversely on external $\left[\mathrm{Ca}^{2+}\right]$ and $\left[\mathrm{Cl}^{-}\right]$. The concentrations of the latter ions may influence the voltage dependence of the response. The slow inward current has many properties in common with inward currents induced in other molluscan neurons by application of neuropeptides or intracellular injections of cyclic nucleotides.

It has become apparent in recent years that peptides are widely utilized by neurons as intercellular messengers (Krieger et al., 1983). Molluscs have provided highly useful models for characterizing actions of such peptides (Greenberg et al,, 1983; Scheller et al., 1983; Lloyd, 1986). Although it is probable that peptides are sometimes utilized as synaptic transmitters, they are often released to act on targets at a distance. To better understand the latter mode of action, we have examined the effects of the peptide L-phenylalanyl-L-methionyl-L-arginyl-Lphenylalanineamide (FMRFamide) on neuron R14 in the abdominal ganglion of the gastropod Aplysia. R14 has very little synaptic input and is thought to be excited primarily by substances in the body fluid (Coggeshall et al., 1966).

FMRFamide was discovered as a cardiac excitor in the clam Macrocallista nimbosa by Price and Greenberg (1977). Immunoreactivity to FMRFamide has been demonstrated in the abdominal ganglion of Aplysia californica (Brown et al., 1985)

\footnotetext{
Received Oct. 19, 1987; revised Mar. 7, 1988; accepted Mar. 9, 1988.

We thank Dr. William D. Willis, Jr. for loan of equipment and Drs. James E. Blankenship, Malcolnu Brodwick, Sherry D. Painter, and Gregg T. Nagle for helpful discussion. We also thank Dr. Cheng-Yie Lin and Mr. Michael Hughes for technical assistance and Ms. Debbie Pavlu for typing the manuscript.

Correspondence should be addressed to Dr. David J. McAdoo, Marine Biomedical Institute, University of Texas Medical Branch, 200 University Boulevard, Galveston, TX 77550.

a Permanent address: Department of Physiology, Shimane Medical University, Izumo, 693, Japan.

Copyright (C) 1988 Society for Neuroscience $0270-6474 / 88 / 103891-10 \$ 02.00 / 0$
}

and in nerve fibers innervating the gill musculature (Weiss et al., 1984). FMRFamide has been isolated from extracts of $A p l y$ sia abdominal ganglia using gel filtration followed by high-pressure liquid chromatography and identified by microsequencing (Rothman et al., 1985). In Aplysia, FMRFamide modulates the activity of specific central neurons (Stone and Mayeri, 1981), inhibits contraction of the gut (Austin et al., 1983), stimulates contractions of the gill (Weiss et al., 1984), and modulates evoked buccal muscle contractions (Richmond et al., 1986). FMRFamide induces an inward $\mathrm{Na}^{+}$current and an outward $\mathrm{K}^{+}$current in neurons L4 and L6 in the Aplysia abdominal ganglion (Ruben et al., 1986), it suppresses a $\mathrm{Ca}^{2+}$ current in Aplysia abdominal ganglion neurons L2-L4, and L6 (Brezina et al., 1987b), and it activates the $\mathrm{K}^{+}$-mediated $\mathrm{S}$ current in these and other Aplysia neurons (Belardetti et al., 1987; Brezina et al., 1987a). FMRFamide also exerts potent effects on central neurons of other molluscs (Cottrell, 1982; Cottrell et al., 1984; Boyd and Walker, 1985). In Helix neurons, FMRFamide decreases a $\mathrm{Ca}^{2+}$ conductance and the S current (Colombaioni et al., 1985).

We describe here a slow inward current induced by FMRFamide. This slow inward current enhanced the negative slope resistance region of the $I-V$ relationship of $\mathrm{R} 14$, possibly thereby increasing the excitability of the neuron. Although this current seems largely carried by $\mathrm{Na}^{+}$, it is influenced by concentrations of $\mathrm{Ca}^{2+}$ and $\mathrm{Cl}^{-}$in the physiological range. Some of this work has been published in an abstract (Ichinose and McAdoo, 1986).

\section{Materials and Methods}

Aplysia californica (150-250 gm) were purchased from Alacrity Marine Biological Services (Redondo Beach, CA). Aplysia brasiliana (50-200 $\mathrm{gm})$ were collected in South Padre Island, Texas. Animals were kept in artificial seawater at ocean temperature $\left(15^{\circ} \mathrm{C}\right)$. The experiments were carried out in vitro on 124 abdominal ganglia. The ganglion was removed from the animal and pinned dorsal side up to the Sylgard base of a 0.2 $\mathrm{ml}$ Lucite chamber. The ganglionic sheath was removed from over R14 after incubating the ganglion in a solution containing $2.5 \mathrm{mg} / \mathrm{ml}$ trypsin or $10 \mathrm{mg} / \mathrm{ml}$ protease for $15-25 \mathrm{~min}$ at $34^{\circ} \mathrm{C}$. $\mathrm{R} 14$ was identified by position, size, color, and electrical activity (Coggeshall ct al., 1966; Frazier et al., 1967).

Normal artificial seawater (NSW) had the following composition: 430 $\mathrm{mm} \mathrm{NaCl}, 10 \mathrm{~mm} \mathrm{KCl}, 10 \mathrm{~mm} \mathrm{CaCl}_{2}, 22 \mathrm{mM} \mathrm{MgCl}_{2}, 26 \mathrm{~mm} \mathrm{MgSO}_{4}$ $10 \mathrm{~mm}$ Tris- $\mathrm{HCl}, \mathrm{pH} 7.8$. Reduced $\mathrm{Na}^{+}$seawater was made by substituting $N$-methyl-D-glucamine for $\mathrm{NaCl}$. In these solutions, the $\mathrm{pH}$ was adjusted to 7.8 with concentrated $\mathrm{HCl}$. This resulted in a reduction of $\left[\mathrm{Cl}^{-}\right]$from normal by $15 \%$ of the amount of $N$-methyl-D-glucamine added. To reduce $\left[\mathrm{K}^{+}\right], \mathrm{KCl}$ was replaced by $\mathrm{NaCl}$. Changes in external $\left[\mathrm{Ca}^{2+}\right]$ were compensated for by adding or subtracting equivalent amounts of $\mathrm{Mg}^{2+} . \mathrm{Cl}^{-}$was replaced by acetate or gluconate ions in low $\left[\mathrm{Cl}^{-}\right]$ solutions. Gluconate by itself was without apparent effects on R14. The bath was continuously perfused at approximately $0.6 \mathrm{ml} / \mathrm{min}$. Experiments were performed at room temperature $\left(22-24^{\circ} \mathrm{C}\right)$. 

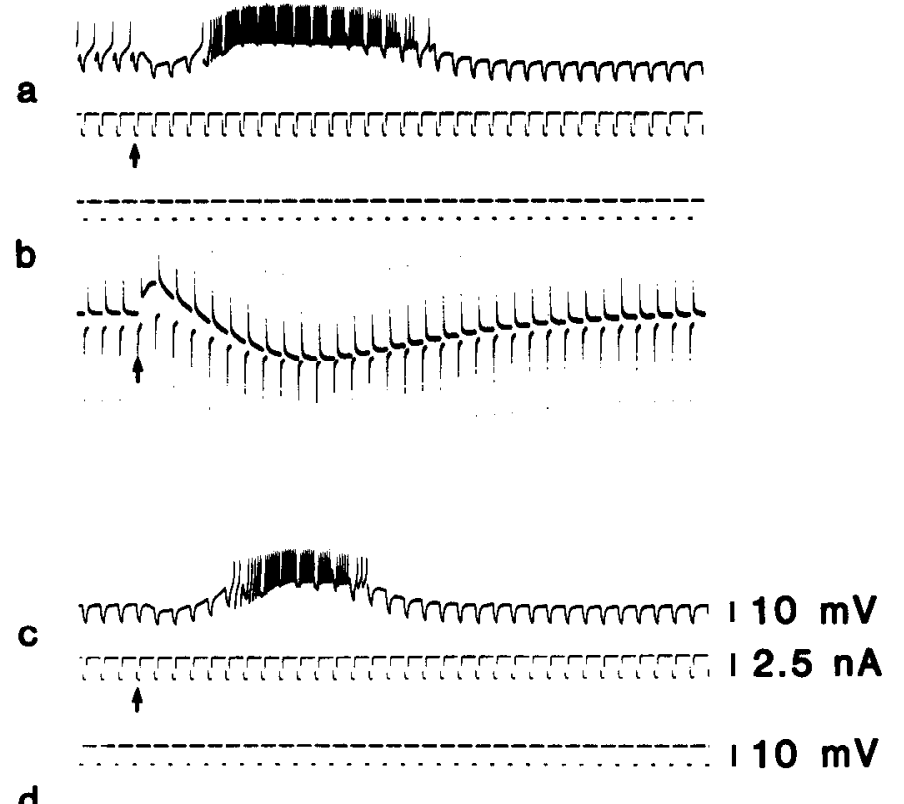

d

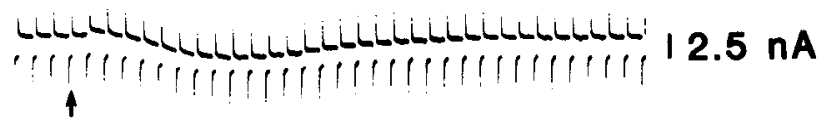

$1 \mathrm{~min}$

Figure 1. Biphasic responses to FMRFamide. Upper trace of each pair shows membrane potential; lower traces, membrane current. $a$ and $c$, Current-clamp recordings at membrane potentials of -50 and $-60 \mathrm{mV}$, respectively; $b$ and $d$, voltage-clamp recordings at holding potentials of -50 and $-60 \mathrm{mV}$, respectively. Constant $10 \mathrm{mV}, 1 \mathrm{sec}$ hyperpolarizing command pulses were injected every $5 \mathrm{sec}$, and the current required to generate the command pulses was recorded to monitor membrane conductance. FMRFamide was ejected by single pneumatic pulses $(1 \mathrm{sec}$, $1 \mathrm{~kg} / \mathrm{cm}^{2}$ ). Upward responses in $a$ and $c$ are depolarizations accompanying action potentials of the neuron. The amplitude is distorted by the limited high-frequency responses of the pen. All records are from the same preparation. After pressure application of the peptide to its soma, R14 first hyperpolarizes, then depolarizes, under current clamp or a fast outward current is induced followed by a slow inward current under voltage clamp.

Cells were impaled with two glass microelectrodes filled with $3 \mathrm{M} \mathrm{KCl}$ (resistance, 5-10 M 2 ) for voltage- and current-clamping (model 8500 , Dagan Corp.). Membrane current was measured using a virtual ground circuit. An $\mathrm{Ag}-\mathrm{AgCl}$ electrode connected to the bath through an agarseawater bridge served as the indifferent electrode and virtual ground. The membrane potential and current were monitored on a dual-beam oscilloscope (Dual Beam Storage 5113, Tektronix). Signals were low pass-filtered at a cut-off frequency of $5 \mathrm{~Hz}$. Permanent records were obtained using a thermal chart recorder (Linerecorder Mark VII Wr 3101 , Graphtec, Irvine, CA). The membrane potential was held at values from $-100 \mathrm{mV}$ to $+10 \mathrm{mV}$ to obtain $I-V$ (current-voltage) curves. To evaluate changes in membrane conductance, hyperpolarizing command pulses ( $10 \mathrm{mV}$ amplitude, $1 \mathrm{sec}$ duration, $0.2 \mathrm{~Hz}$ ) were injected into the neuron during voltage clamp.

FMRFamide (Peninsula Lab, Belmont, CA) was applied to the soma from a glass micropipette with an orifice diameter of approximately 5$10 \mu \mathrm{m}$ by a pressure pulse $\left(0.5-1.0 \mathrm{~kg} / \mathrm{cm}^{2}\right.$, duration $\left.0.5-2.0 \mathrm{sec}\right)$ using a pneumatic pump (Neurophore BH-2, Medical System Corp.). The delivery pipette was positioned close to the cell body. This pipette was filled with $1 \mathrm{mg} / \mathrm{ml} \mathrm{FCF} \mathrm{Fast} \mathrm{green} \mathrm{(Allied} \mathrm{Chemical,} \mathrm{NY)} \mathrm{and} 0.2 \mathrm{~mm}$ of FMRFamide dissolved in NSW. The dye was used to verify ejection of the solution onto the neuron visually. Control ejections of Fast green had no effect on the neuron. The estimated volumes ejected were about $0.5 \mathrm{nl}$.

$N$-Methyl-D-glucamine, TTX, and sodium gluconate were purchased from Sigma.

\section{Results}

Characteristics of FMRFamide-induced current

Pressure-ejected FMRFamide caused a marked depolarization, usually leading to the generation of action potentials when R14 was current-clamped (Fig. 1, $a, c$ ). FMRFamide induced a slow inward current in 86 out of 90 neurons studied. This response is characterized here. FMRFamide also induced inward current in neurons R4-R8, members of a cluster thought to be closely related to $\mathrm{R} 14$. The slow inward current maximized within 0.5$1 \mathrm{~min}$ and lasted at least $2 \mathrm{~min}$. Pressure-ejected FMRFamide also sometimes triggered a fast outward current (Figs. 1, 5, inset; 6 cells out of 90 ) or a fast inward current ( 40 cells out of 90 preparations; Fig. 6). The faster currents were accompanied by conductance increases, which peaked within $10 \mathrm{sec}$. At a holding potential of $-50 \mathrm{mV}$, the slow inward current induced by FMR Famide increased with increasing duration or amplitude of the pressure pulse (not shown).

The threshold for the response was determined by applying FMRFamide to the ganglion by perfusion. One minute bath applications of FMRFamide resulted in dose-dependent increases in inward current in R14 with a threshold of about $10^{-7}$ M (Fig. 2). The response to bath-applied FMRFamide resembled the slow response to pressure-ejected FMRFamide. The response maximized at $10^{-5} \mathrm{M}$ FMRFamide, decreasing at $10^{-4}$ $\mathrm{M}(n=3)$.

\section{Desensitization of FMRFamide-induced inward current}

The slow inward current decreased with successive applications of FMRFamide (Fig. 3). Recovery from desensitization increased with lengthening intervals between applications and was complete in $8 \mathrm{~min}$ (Fig. 3). The responses to the 10th ejection wcre reduced to $32 \%$ of the initial response at the shortest in terval between applications examined, $2.5 \mathrm{~min}$. When FMRFamide was applied by perfusion, later responses did not regain the amplitude of the initial response even after 45-56 min of washout (not shown). Therefore, in most experiments FMRFamide was applied by pressure ejection at intervals of at least $8 \mathrm{~min}$.

\section{Voltage dependence of the FMRFamide-induced slow inward current}

To characterize the voltage dependence of the FMRFamideinduced slow inward current, the membrane of R 14 was clamped and the amplitude of the FMRFamide-induced current measured at potentials from -100 to $-35 \mathrm{mV}$ (Fig. 4). The resting membrane potential of $\mathrm{R} 14$ was $-54 \pm 7 \mathrm{mV}$ (mean $\pm \mathrm{SD}$, $n=86$ ). A spike-like inward current was observed above -35 $\mathrm{mV}$, making the holding current unstable. Therefore, in most experiments, responses to FMRFamide were studied only at potentials more hyperpolarized than $-35 \mathrm{mV}$. The FMRFamide-induced inward current increased over the voltage range $-100 \mathrm{mV}$ to $-35 \mathrm{mV}$. At holding potentials in the range of -80 to $-40 \mathrm{mV}$, current changes in response to hyperpolarizing voltage pulses decreased in amplitude upon activation of the FMRFamide-induced slow inward current (Fig. 4, $A b-f$ ). As the holding potential was raised, the direction of the current pulses inverted. This happened at about $-40 \mathrm{mV}$ during FMRFamide application and at slightly higher potentials when FMRFamide was not present (Fig. 4Aa). This inversion is due to entry into the negative slope resistance (NSR) region of the $I-V$ relationship. 

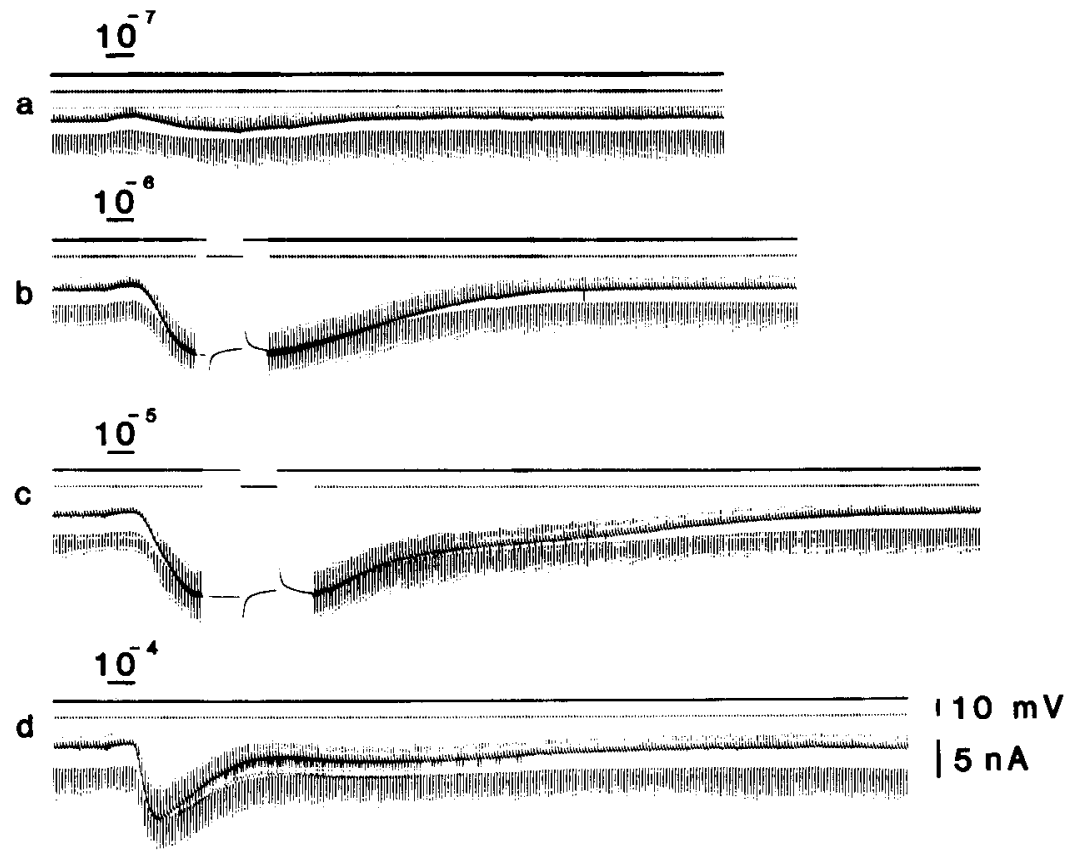

1 min
Figure 2. Relationship under voltage clamp $(-50 \mathrm{mV})$ between the inward current of R14 and the concentration of FMRFamide bath-applied for $1 \mathrm{~min}$ (indicated by the bars below the concentrations). Upper traces of each pair, voltage monitor. Downward steps in voltage traces are hyperpolarizing pulses (amplitude, $10 \mathrm{mV}$; duration, $1 \mathrm{sec}$; interval, $5 \mathrm{sec}$ ). Lower trace, current monitor. Deflections indicate the membrane conductance. The amount of current flowing through the membrane during the constant-voltage steps decreases in the presence of FMRFamide. In $b$ and $c$, the time scale is expanded at the peak of the responses.
$I-V$ curves were measured before and at the peak of the FMRFamide-induced response in R14 using command pulses from a holding potential of $-50 \mathrm{mV}$ (Fig. 5). The control $I-V$ relationship for R14 is N-shaped. FMRFamide shifted the NSR region to slightly more negative potentials. The difference $I-V$ curve representing the net response to FMRFamide was obtained by subtracting the amplitude of the current pulse before the application of FMRFamide from that at the peak of the FMRFamide-induced response at each command pulse voltage. The difference $I-V$ curve (Fig. $6 B$ ) shows that the amplitude of the FMRFamide-induced inward current first increased and then decreased as the command pulses became more depolarizing. Thus, the slow inward current produced by FMRFamide is voltage sensitive. The membrane potential at the onset of the NSR region was between $-50 \mathrm{mV}$ and $-40 \mathrm{mV}$ among preparations.

\section{Role of $\left[\mathrm{Na}^{+}\right]$}

Reducing $\left[\mathrm{Na}^{+}\right]$reversibly decreased the FMRFamide-induced inward current (Fig. 7). Complete replacement of $\mathrm{Na}^{+}$with $N$-methyl-D-glucamine decreased the FMRFamide-induced current to $12 \%(n=3)$ of control after $18 \mathrm{~min}$ of $\mathrm{Na}^{+}$-free perfusion. The FMRFamide-induced inward current was completely restored $36 \mathrm{~min}$ after return to normal seawater. This identifies $\mathrm{Na}^{+}$as the major current-carrying ion in the FMRFamide-induced inward current, but the residual current in the absence of $\mathrm{Na}^{+}$suggests a contribution from a second species.

To confirm the $\mathrm{Na}^{+}$dependence of the FMRFamide-induced slow inward current, the reversal potential of the response was estimated from difference $I-V$ curves (Fig. 6). Substituting $\mathrm{Co}^{2+}$ for $\mathrm{Ca}^{2+}$ made possible voltage clamping up to $+10 \mathrm{mV}$ in small cells, possibly by eliminating $\mathrm{Ca}^{2+}$ currents and $\mathrm{Ca}^{2+}$-dependent $\mathrm{K}^{+}$currents. Extrapolating the difference $I-V$ curve in the depolarizing direction to zero current gave a reversal potential of $+28 \mathrm{mV}($ mean $\pm \mathrm{SE}, n=4)$.
Total replacement of $\mathrm{NaCl}$ with $\mathrm{LiCl}$ did not change the slow inward current in R14 significantly $(1.41 \pm 0.41$, mean $\pm \mathrm{SE}$; $n=4$; Fig. $8 A)$. The $\mathrm{Na}^{+}$channel blocker TTX $(30 \mu \mathrm{M})$ inhibited the FMRFamide response slightly (Fig. $8 B$ ) after perfusion for $22 \min (0.84 \pm 0.06$, mean $\pm \mathrm{SE} ; n=4 ; p<0.05, t$ test $)$. The $\mathrm{Na}^{+}-\mathrm{K}^{+}$pump inhibitor, ouabain $(50 \mu \mathrm{M})$ had no obvious effect (Fig. 8C).

\section{Investigations of possible $\mathrm{K}^{+}$-current contributions}

Varying $\left[\mathrm{K}^{+}\right]$from $50 \mathrm{~mm}$ to $5 \mathrm{~mm}$ caused little change in the FMRFamide-induced current recorded at a holding potential of $-50 \mathrm{mV}$ (Fig. 9), suggesting that the FMRFamide response

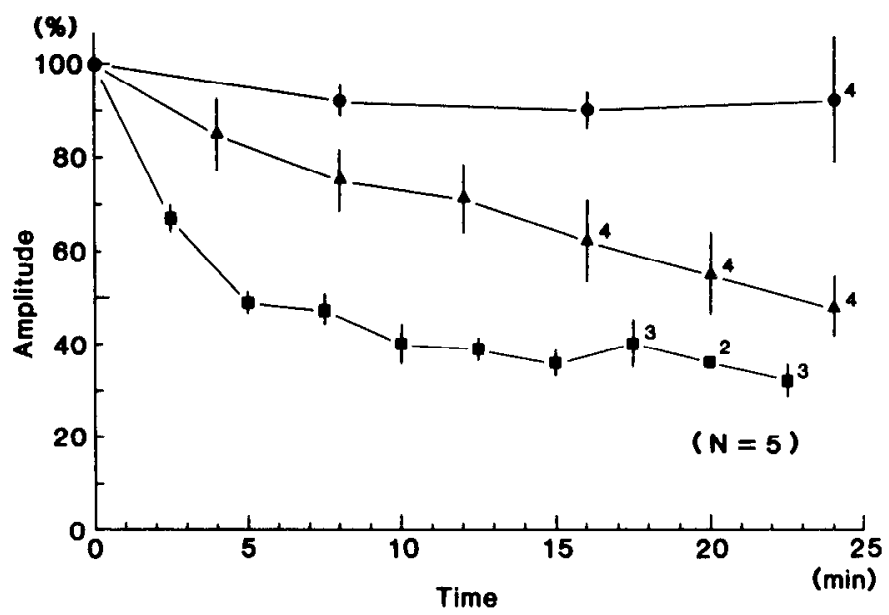

Figure 3. Relationship between amplitude (inward current) of FMRFamide response and the interval between ejections. The data are from 5 preparations. Numbers of experiments are above each point if less than 5 . The points without numbers come from one experiment in each of 5 preparations. Circles, triangles, and squares are 8, 4, and 2.5 min intervals, respectively. Membrane potential was clamped at -50 $\mathrm{mV}$. 


\section{A}

Figure 4. Voltage dependence of the FMRFamide-induced slow inward current in R14. $A$, FMRFamide-induced slow inward currents recorded at a series of holding potentials (indicated at the right of each trace). Constant hyperpolarizing command voltage pulses with durations of $1 \mathrm{sec}$ were injected every $5 \mathrm{sec}$. FMRFamide was applied by single constant pulses $(1 \mathrm{sec}, 1 \mathrm{~kg} /$ $\mathrm{cm}^{2}$ ). Note the inversion of the current and voltage traces indicating an apparent negative resistance at a holding potential of $-35 \mathrm{mV}(a)$. $B$. Voltage sensitivity of the FMRFamide-induced inward current obtained from 5 different preparations. The amplitude of the inward current increased at more depolarizing voltages and decreased at morc hypcrpolarizing potential levels. Numbers close to the points are the numbers of neurons examined. Error bars represent SE.
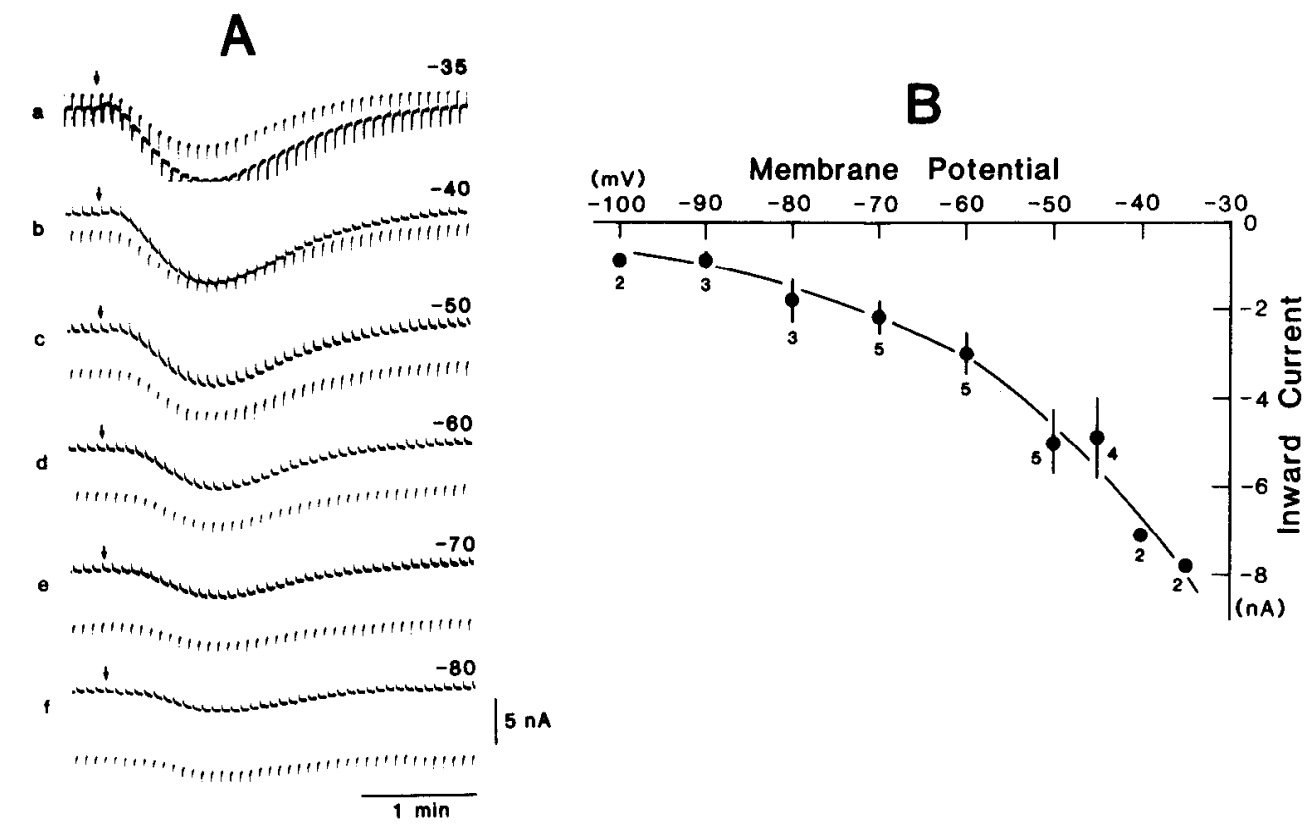

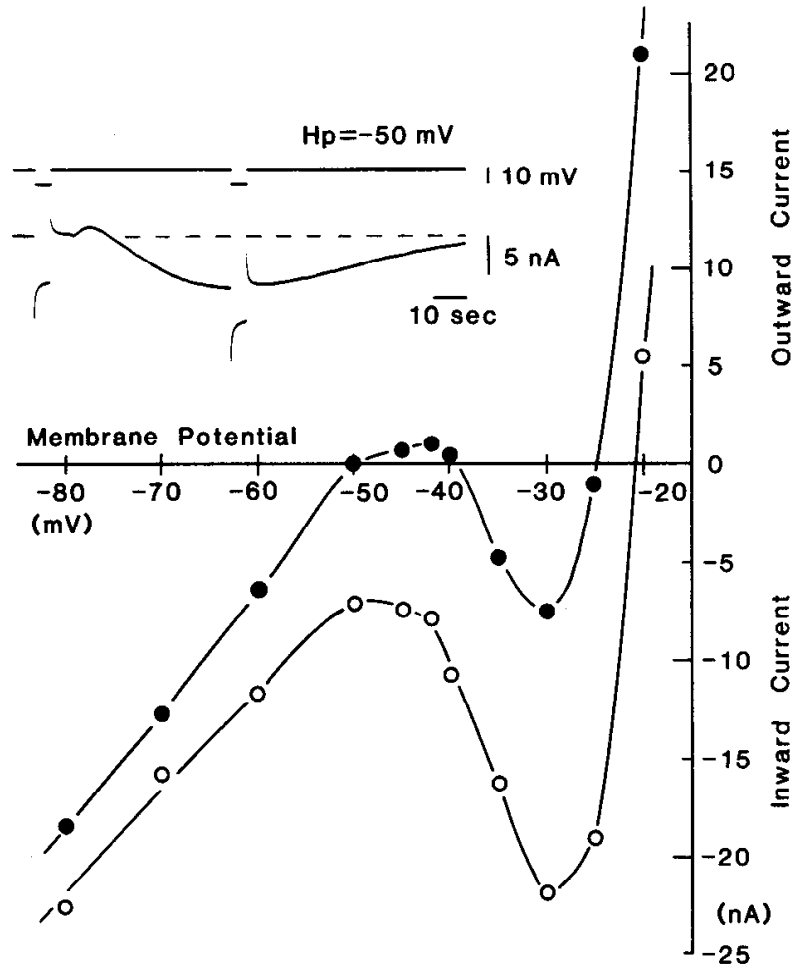

Figure 5. Comparison of the $I-V$ curves obtained before (closed circles) and at the peak of the FMRFamide-induced inward current (open circles). $I-V$ curves were obtained by varying the amplitude of both depolarizing and hyperpolarizing $5 \mathrm{sec}$ command pulses from a holding potential of $-50 \mathrm{mV}$. Experiments were conducted in NSW. Inset, Example of the FMRFamide-induced slow inward current. Hyperpolarizing command pulses (duration, $5 \mathrm{sec}$ ) were applied before and at the peak of the FMRFamide-induced inward current. Note that the NSR region of the $I-V$ curve was enhanced by focal application of FMRFamide.
A
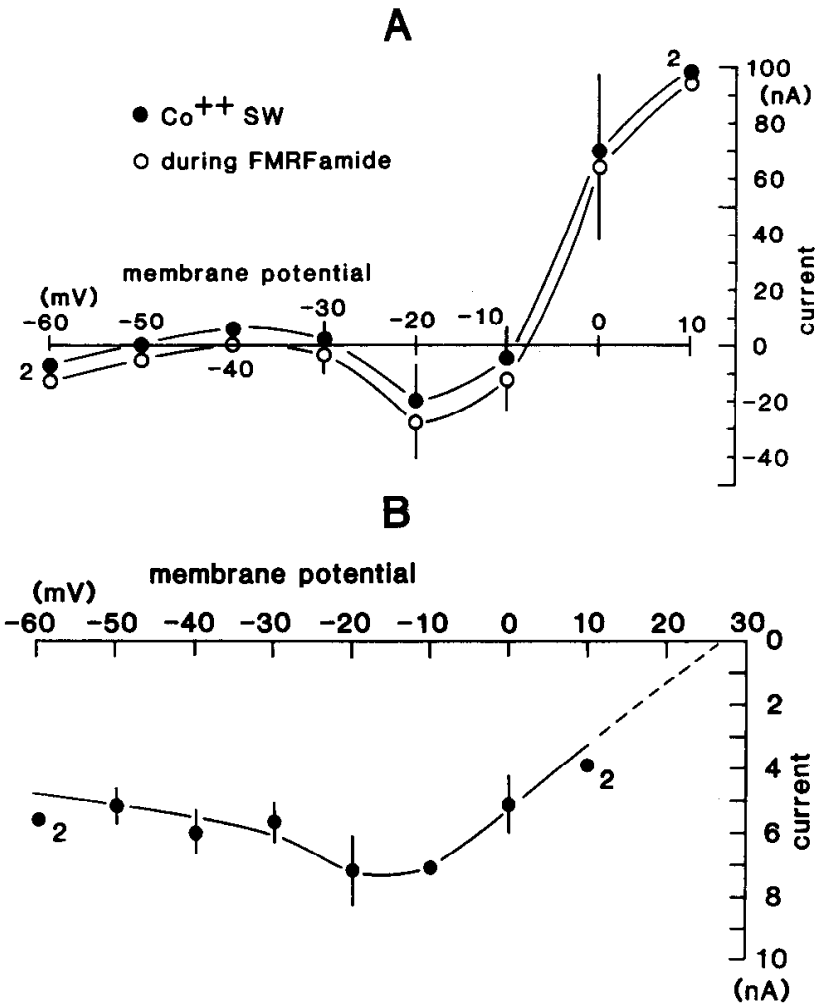

Figure 6. The $I-V$ relationship for the response of R 14 to FMRFamide. $A, I-V$ curves obtained before (closed circles) and at the peak of the FMRFamide response (open circles). $\mathrm{Co}^{2+}$ substitution was used to block $\mathrm{Ca}^{2+}$ channels and $\mathrm{Ca}^{2+}$-activated $\mathrm{K}^{+}$channels throughout the experiment. This enabled us to extend the experimental measurements to higher membranc potentials (sec text). The data arc from 4 experiments except the $-60 \mathrm{mV}$ and $+10 \mathrm{mV}$ points, which are from 2 experiments. $B$, Difference $I-V$ curve indicating the approximate reversal potential for the FMRFamide response. The mean extrapolated reversal potential from 4 preparations is $+28 \pm 6 \mathrm{mV}( \pm \mathrm{SE} ; n=4)$. SE of the $-10 \mathrm{mV}$ point is less than the diameter of the point. 


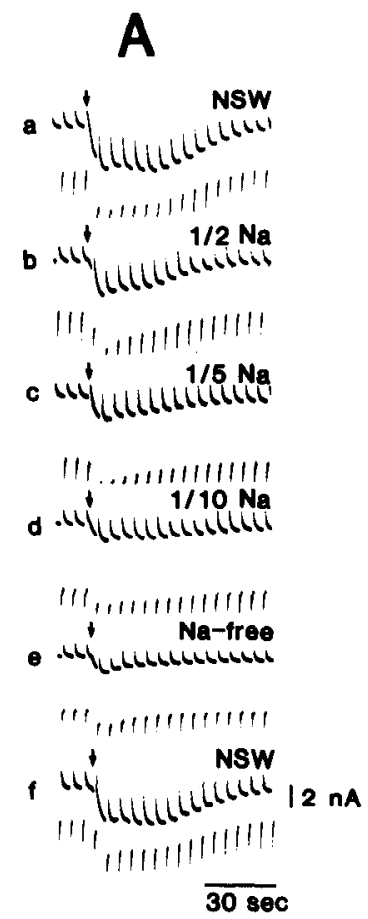

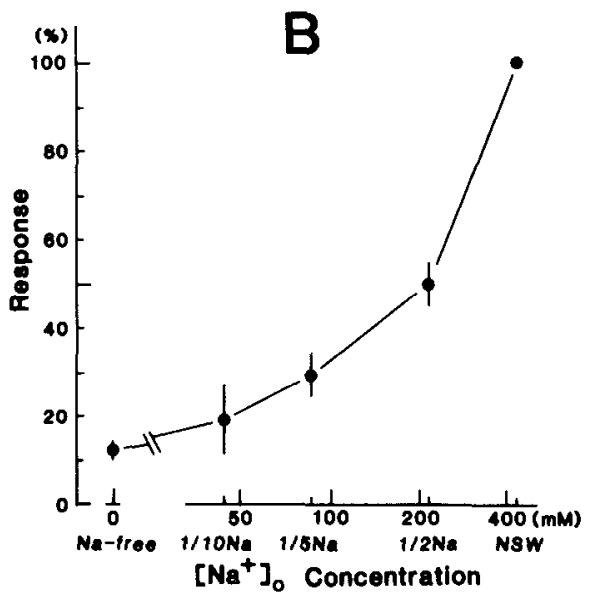

contains little contribution from a $\mathrm{K}^{+}$-conductance change. To test the $\mathrm{K}^{+}$independence of the slow FMRFamide response, the effects of the $\mathrm{K}^{+}$-channel blockers tetraethyl ammonium (TEA) and 4-aminopyridine (4-AP) on the FMRFamide response were investigated (not shown). A combination of bath-applied 4-AP ( $5 \mathrm{~mm})$ and TEA (30 $\mathrm{mm}$ ) increased the amplitude of the FMRFamide-induced slow inward current $(1.61 \pm 0.26$, mean $\pm \mathrm{SE} ; n=5 ; p<0.05, t$ test). Application of these agents decreased the membrane resistance to $0.72 \pm 0.26$ times control (mean $\pm \mathrm{SE}, n=5, p<0.05, t$ test). Replacing $\mathrm{Ca}^{2+}$ with 10 mM Co${ }^{2+}$, which would block any $\mathrm{Ca}^{2+}$-dependent $\mathrm{K}^{+}$current arising from $\mathrm{Ca}^{2+}$ influx, had little effect on the response to FMRFamide (see Fig. 12Aa). The FMRFamide-induced current persisted (Fig. 4) when R14 was clamped at voltages below the
Figure 7. Effects of lowering external $\left[\mathrm{Na}^{+}\right]$. $\left(\mathrm{Na}^{+}\right.$was replaced by $N$-methylD-glucamine.) $A$, FMRFamide was applied at arrowhead in each trace. In this preparation, the conductance associated with the fast inward current increased. The diminished pulse amplitudes associated with the later slow inward current can be seen in each trace. Holding potential was $-50 \mathrm{mV}$; pulse injections as in Figure $1 d$ in all experiments. $a$, In normal seawater; $b$, after $12 \mathrm{~min}$ in $0.5 \times\left[\mathrm{Na}^{+}\right]$solution; $c$, after $14 \mathrm{~min}$ in $0.2 \times\left[\mathrm{Na}^{+}\right]$solution; $d$, after $15 \mathrm{~min}$ in $0.1 \times\left[\mathrm{Na}^{+}\right]$solution; $e, 18$ min after complete $\mathrm{Na}^{+}$replacement with $N$-methyl-D-glucamine; $f, 41 \mathrm{~min}$ after return to control $\left[\mathrm{Na}^{+}\right] . B$, External $\left[\mathrm{Na}^{+}\right]$dependence of FMRFamideinduced slow inward current. The data in $B$ are mean values ( $\pm \mathrm{SE}$ ) of 3 experiments using different preparations and normalized as a percentage of the current in NSW.
$\mathrm{K}^{+}$and $\mathrm{Cl}^{-}$equilibrium potentials of Aplysia neurons L1-L6, $-76 \mathrm{mV}$ and $-57 \mathrm{mV}$, respectively (Kunze and Brown, 1971).

\section{Dependence on external $\left[\mathrm{Ca}^{2+}\right]$}

The influence of extracellular $\left[\mathrm{Ca}^{2+}\right]$ on the FMRFamide-induced inward current is illustrated in Figure 10. Reducing $\left[\mathrm{Ca}^{2+}\right]$ from 10 to $2 \mathrm{mM}$ (compensated by $\mathrm{Mg}^{2+}$ ) caused an increase (144 $\pm 10 \%$ of control, mean \pm SE; $n=3$ ) in the FMRFamideinduced inward current. Furthcrmore, the current was reduced (to $88 \pm 2 \%$ of control, mean $\pm \mathrm{SE} ; n=3$ ) when $\mathrm{R} 14$ was exposed to high- $\mathrm{Ca}^{2+}(20 \mathrm{mM})$ seawater.

Preliminary to determining the effects of the divalent ions [Co ${ }^{2+}\left(10 \mathrm{~mm}\right.$, substituted for $\left.\mathrm{Ca}^{2+}\right), \mathrm{Ni}^{2+}(20 \mathrm{~mm}$, added to $\mathrm{NSW}), \mathrm{Mn}^{2+}$ (20 mM, added to NSW), and $\mathrm{Ba}^{2+}(20 \mathrm{~mm}$, added
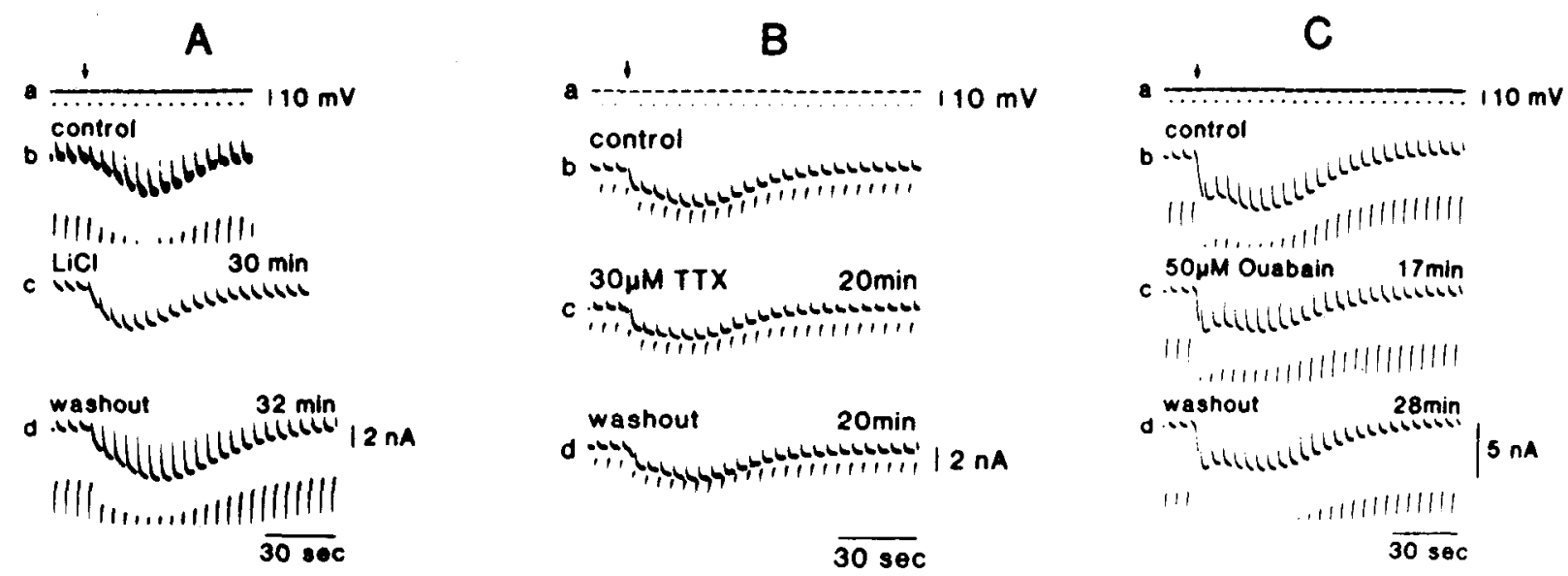

Figure 8. Effects of $\mathrm{Na}^{+}$- related drugs on the slow inward current. $A$, External $\mathrm{Na}^{+}$was replaced with $\mathrm{Li}^{+}$. The current responses to hyperpolarizing pulses increased $2.08 \pm 0.13$ times (mean $\pm \mathrm{SE}$ ) of control $(n=5, p<0.05)$ during perfusion with $\mathrm{Li}^{+}$solution, causing the lower part of the recording to disappcar in $c . B$, TTX $(30 \mu \mathrm{M})$ decreased the response amplitude to $84 \pm 6 \%$ (mean \pm SE) of the control response $(n=4, p<0.05)$. $C$, Ouabain $(50 \mu \mathrm{M})$ had no effect on the membrane conductance $(93 \pm 12 \%$, mean $\pm \mathrm{SE} ; n=4)$ or response amplitude $(106 \pm 11 \%$, mean $\pm \mathrm{SE}$; $n=4$ ). 
Figure 9. Dependence of responses on external $\left[\mathrm{K}^{+}\right] . A, a$, voltage monitor during the voltage clamp; $b$, after $8 \mathrm{~min}$ of perfusing with $2 \times\left[\mathrm{K}^{+}\right] ; c$, after 8 min of perfusion with normal artificial seawater; $d$, after perfusing for $9 \mathrm{~min}$ with $0.2 \times\left[\mathrm{K}^{+}\right]$solution; $e$, after 11 min of perfusing with $0.1 \times\left[\mathrm{K}^{+}\right]$solution. $B$, Mean $( \pm S E)$ of 3 experiments each on a different preparation. Data were normalized to the control inward current in normal seawater $(=100 \%) . \mathrm{K}^{+}$was replaced with $\mathrm{Na}^{+}$to reduce external $\left[\mathrm{K}^{+}\right]$. Holding potential, $-50 \mathrm{mV}$.
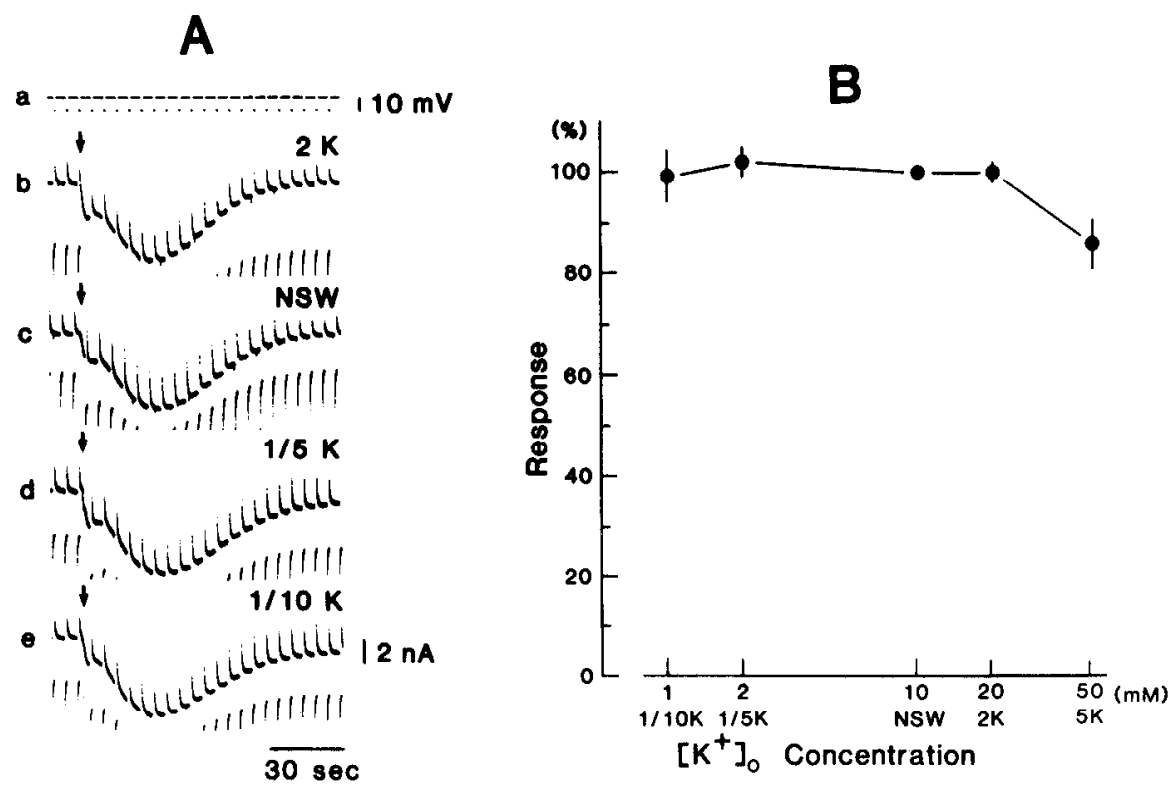

to NSW)] on the response to FMRFamide, their effects on the control $I-V$ curve were determined (Fig. 11). These ions all (1) inhibited the inward current at potentials more hyperpolarizing than $-70 \mathrm{mV}$, (2) shifted the NSR in the depolarizing direction, (3) enhanced the trough of the negative resistance region, and (4) shifted the onset of the outward current from about -20 $\mathrm{mV}$ to near $0 \mathrm{mV}$.

The effects of divalent cations on responses to FMRFamide are shown in Figure 12. $\mathrm{Co}^{2+}(10 \mathrm{~mm})$ substitution for $\mathrm{Ca}^{2+}$ had little effect $(111 \pm 5 \%$; mean $\pm \mathrm{SE} ; n=4)$. Addition of $20 \mathrm{~mm}$ $\mathrm{Ni}^{2+}$ or $\mathrm{Ba}^{2+}$ to NSW also did not significantly affect the FMRFamide response, $133 \pm 28 \%( \pm \mathrm{SE} ; n=3)$ and $85 \pm 11 \%$ $( \pm \mathrm{SE} ; n=5$ ), respectively. However, higher concentrations of $\mathrm{Ni}^{2+}(50 \mathrm{~mm})$ or $\mathrm{Ba}^{2+}(50 \mathrm{~mm})$ reduced the FMRFamide-induced inward current to $18 \pm 6 \%$ (mean $\pm \mathrm{SE} ; n=4$; Fig. $12 C$ ) and to $56 \pm 16 \%$ (mean $\pm \mathrm{SE} ; n=4$; Fig. $12 E$ ), respectively.

\section{Effects of external $\left[\mathrm{Cl}^{-}\right]$}

The role of $\mathrm{Cl}^{-}$in the FMRFamide-induced current was explored by replacing $\mathrm{Cl}^{-}$with acetate or gluconate (Fig. 13). When $\mathrm{Cl}^{-}$was reduced to 0.2 times, the amplitude of the FMRFamide response increased to $137 \pm 11 \%$ (mean $\pm \mathrm{SE} ; n=3$ ) upon acetate substitution and to $297 \pm 91 \%$ (mean $\pm \mathrm{SE} ; n-3)$ upon gluconate substitution (Fig. 13B). Replacement of $\mathrm{Cl}^{-}$diminished the amplitude of current pulses produced by hyperpolarizing voltage pulses (Fig. 13A).

\section{Discussion}

The results presented here demonstrate that FMRFamide induces a voltage-sensitive, slow inward current in neuron R14 of Aplysia. This current appears to be chiefly carried by $\mathrm{Na}^{+}$. FMRFamide-induced inward currents in neurons of various
Figure 10. External $\left[\mathrm{Ca}^{2+}\right]$ dependence of FMRFamide response. $A, a$, Voltage monitor; $b$, after $8 \mathrm{~min}$ of perfusing with $2 \times\left[\mathrm{Ca}^{2+}\right] ; c$, control response in normal seawater; $d$, after 8 min of perfusing with $0.5 \times\left[\mathrm{Ca}^{2+}\right] ; e$, after $8 \mathrm{~min}$ of perfusing with $0.2 \times$ $\left[\mathrm{Ca}^{2+}\right] . \mathrm{Ca}^{2+}$ was replaced with $\mathrm{Mg}^{2+} . B$, Mean ( \pm SE) of 3 experiments using different preparations. Holding potential was $-50 \mathrm{mV}$. Raising $\left[\mathrm{Ca}^{2+}\right]$ 2-fold reduced the FMRFamide response to 88 $\pm 2 \%$ (mean $\pm \mathrm{SE} ; n=3$ ). On the other hand, the response increased to $121 \pm$ $3 \%$ (mean $\pm \mathrm{SE} ; n=3$ ) in $0.5 \times\left[\mathrm{Ca}^{2+}\right]$ and to $144 \pm 10 \%($ mean $\pm \mathrm{SE} ; n=3)$ in $0.2 \times\left[\mathrm{Ca}^{2+}\right]$.
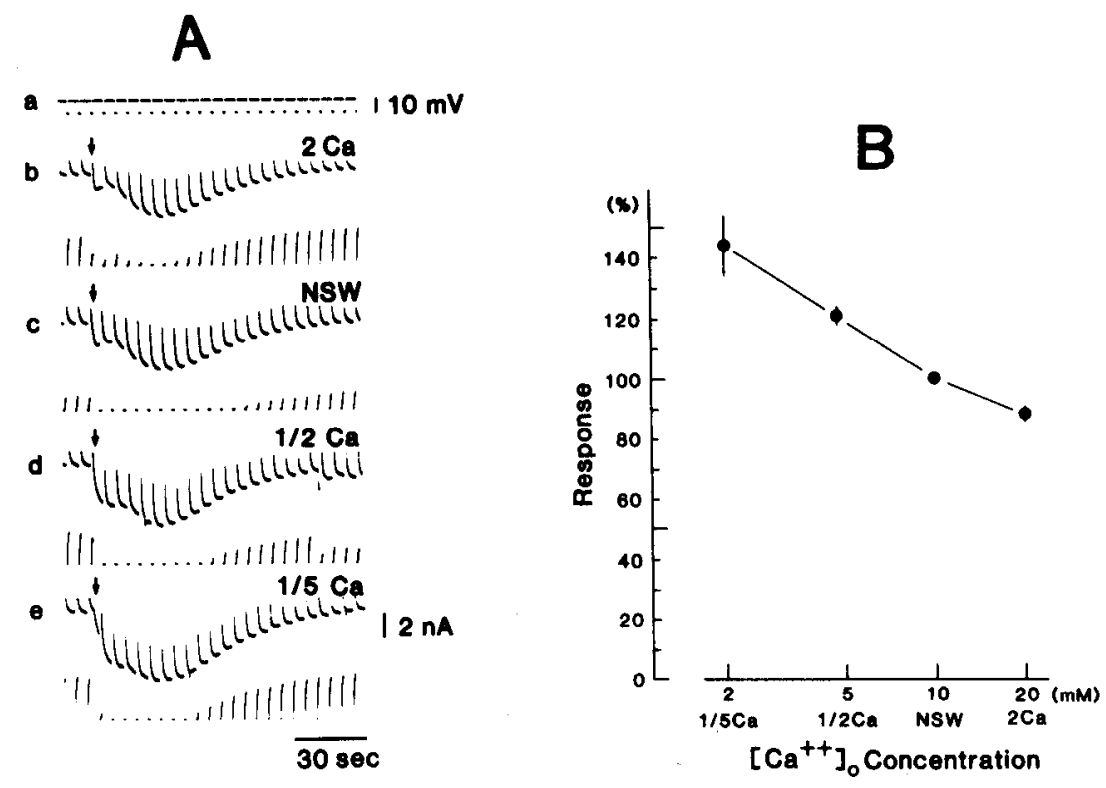


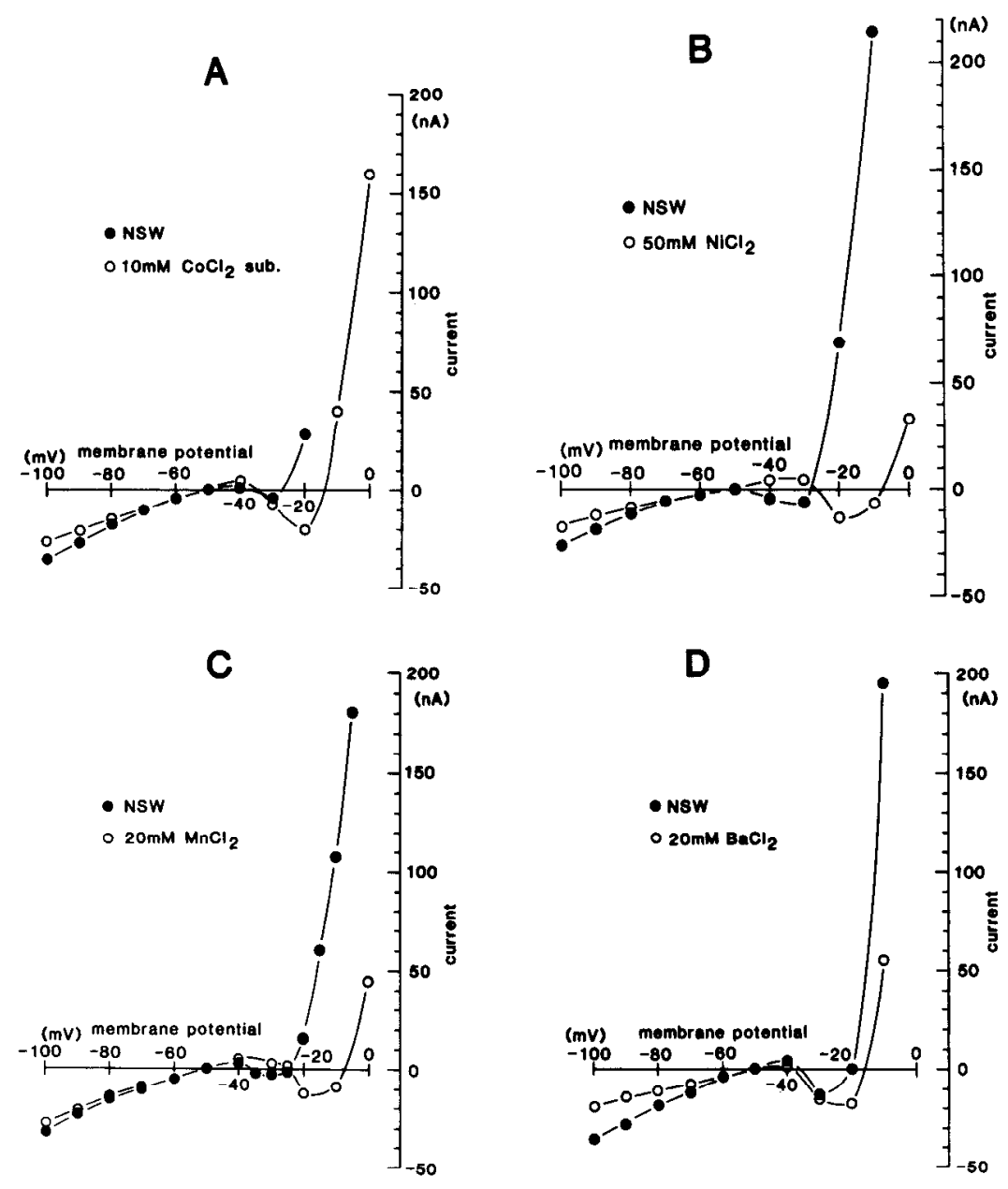

Figure 11. Effects of divalent cations on the $I-V$ curve. $A, \mathrm{Co}^{2+}(10 \mathrm{~mm})$ substitution for $\mathrm{Ca}^{2+} . B, \mathrm{Ni}^{2+}(50 \mathrm{~mm})$ added to NSW. C, $\mathrm{Mn}^{2+}(20 \mathrm{~mm})$ added to NSW. $D, \mathrm{Ba}^{2+}(20 \mathrm{~mm})$ added to NSW. Reduction of the outward current at 0 $\mathrm{mV}$ by $\mathrm{Ba}^{2+}$ is smaller than that by $\mathrm{Ni}^{2+}$ and $\mathrm{Mn}^{2+}$. gastropod species have been proposed to involve either increases in $\mathrm{Na}^{+}$current (Cottrell et al., 1984; Boyd and Walker, 1985; Ruben et al., 1986) or decreases in the $\mathrm{Ca}^{2+}$-activated $\mathrm{K}^{+}$current (Cottrell et al., 1984). Current pulses induced by hyperpolarizing voltage pulses were reduced during FMRFamide application as the holding potential became more depolarized and turned outward above $-40 \mathrm{mV}$. This is caused by a shift of the onset of the NSR region to a more negative membrane potential rather than a conductance decrease. Similar voltage dependencies of responses of buccal ganglion neuron B16 to Aplysia egg-laying hormone (Kirk and Scheller, 1986) and of Aplysia neurons L2L6 to intracellular injections of cAMP (Connor and Hockberger, 1984; Hara et al., 1985) have been observed. Connor and Hockberger established by intracellular measurements with ion-sensitive electrodes that $\mathrm{Na}^{+}$was the major charge-carrying ion in the responses of Archidoris and Aplysia neurons to intracellular injections of cAMP. The slow response of R14 to FMRFamide is slower than the $\mathrm{Na}^{+}$-conductance increases induced by FMRFamide in Helix neurons (Cottrell et al., 1984; Boyd and Walker, 1985) and in neurons L4 and L6 of Aplysia (Ruben et al., 1986).

The FMRFamide-induced inward current in R14 desensitized rapidly. Although it normally took $8 \mathrm{~min}$ to fully recover from desensitization, immediate recovery to control amplitudes followed moving the FMRFamide pipette to a different area of the cell surface. This suggests that desensitization occurred at membrane receptors on the cell surface rather than in an internal signal-transferring system. Inward current induced in R14 by neutral amino acids shows little desensitization (Ichinose and McAdoo, 1985; Ichinose et al., 1985).

TTX inhibited the FMRFamide-induced slow inward current in R14 only slightly. The slow inward current responsible for the negative resistance region in the $\mathrm{R} 14 I-V$ curve also appeared to be resistant to TTX. Thus far, slow inward currents induced by application of peptides (Kirk and Scheller, 1986; Ruben et al., 1986) and injection of cyclic nucleotides (Aldenhoff et al., 1983; Kononenko et al., 1983; Connor and Hockberger, 1984; Hara et al., 1985) seem generally resistant to TTX, even though some are clearly carried mainly by $\mathrm{Na}^{+}$. The FMRFamide-induced slow inward current in $\mathrm{R} 14$ is not the result of $\mathrm{Na}^{+}$$\mathrm{K}^{+}$pump inhibition because the response persisted in ouabain, which has been shown to inhibit the $\mathrm{Na}^{+}$pump in $\mathrm{R} 14$ (Willis et al., 1974), and upon replacement of $\mathrm{Na}^{+}$with $\mathrm{Li}^{+}$. FMRFamide-induced inward currents persist in Aplysia neurons L4 and L6 upon replacement of $\mathrm{Na}^{+}$with $\mathrm{Li}^{+}$(Ruben et al., 1986), as do responses to intracellular injections of cyclic nucleotides (Aldenhoff et al., 1983; Connor and Hockberger, 1984; Hara et al., 1985). The reversal potential of the FMRFamide response obtained by extrapolation of the difference $I-V$ curve is $+28 \mathrm{mV}$. This is close to the apparent reversal potential of the inward current induced by FMRFamide in Aplysia neurons L4 and L6 but below the expected $\mathrm{Na}^{+}$-equilibrium potential (Ruben et al., 1986). Even so, the reversal potential indicates the current is largely carried by inward flow of $\mathrm{Na}^{+}$or $\mathrm{Ca}^{2+}$. We conclude from 


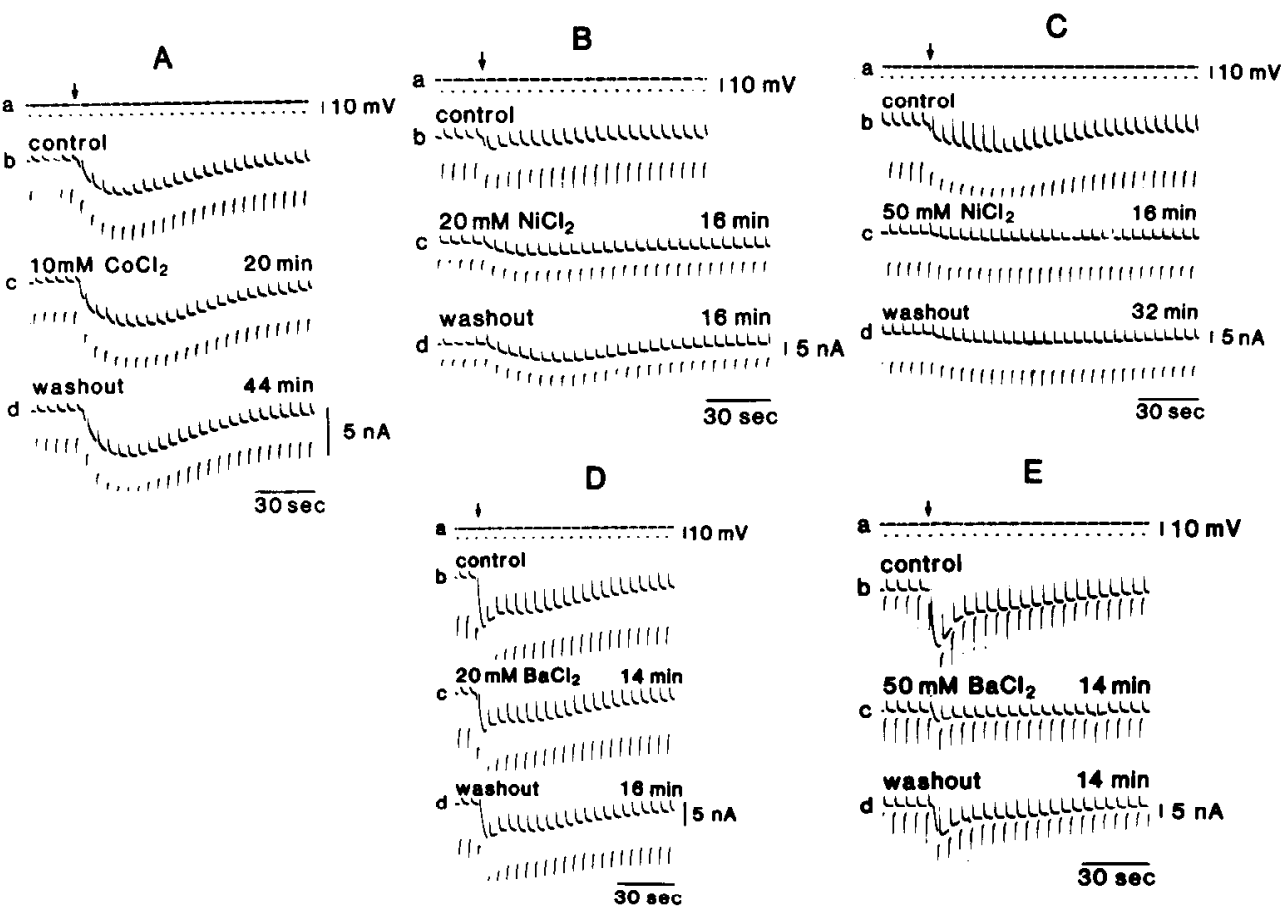

Figure 12. Effects of divalent cations on the FMRFamide-induced slow inward current. $A, \mathrm{Co}^{2+}$ substituted for $\mathrm{Ca}^{2+}, B, \mathrm{Ni}^{2+}(20 \mathrm{~mm})$ added. $C, \mathrm{Ni}^{2+}$ (50 $\mathrm{mm}$ ) added. $D, \mathrm{Ba}^{2+}(20 \mathrm{~mm})$ added. $E, \mathrm{Ba}^{2+}(50 \mathrm{~mm})$ added. $a$, Voltage monitor; $b$, control response in NSW; $c$, response during perfusion with divalent cation-containing solutions; $d$, response after washout.

the reversal potential, ion-substitution experiments, and pharmacological experiments that the FMRFamide response is mainly caused by a voltage-dependent, slow inward current carried by $\mathrm{Na}^{+}$. It may also contain small contributions, at most ca. $12 \%$, from other sources (see following).

The high reversal potential rules out $\mathrm{K}^{+}$and $\mathrm{Cl}^{-}$as the main current carriers. Furthermore, no $\mathrm{K}^{+}$dependence of the FMRFamide response was observed. The preceding characteristics demonstrate that the major part of the FMRFamide response is not a $\mathrm{K}^{+}$-conductance decrease and that any $\mathrm{K}^{+}$-conductance increase present is minor relative to the inward current.

The inverse dependence of the response to FMRFamide on $\left[\mathrm{Cl}^{-}\right]$is novel, although analogous effects of $\mathrm{Cl}^{-}$on an $\mathrm{Na}^{+}$current (Hara et al., 1985) and a mixed $\mathrm{Na}^{+}-\mathrm{K}^{+}-\mathrm{Ca}^{+}$current (Kononenko et al., 1983), both induced by cAMP, have been reported. Inhibition by $\mathrm{Cl}^{-}$of $\mathrm{Na}^{+}$passage through cAMP-activated channels was suggested in both previous studies, and is a possible explanation here. The FMRFamide-induced inward current is not largely due to a decreased $\mathrm{Cl}^{-}$conductance, as if it were the current recorded at a holding potential of $-60 \mathrm{mV}$, the equilibrium potential for chloride in Aplysia neurons L1L6 (Kunze and Brown, 1971), would decrease or change from inward to outward during exposure to $\mathrm{a} \mathrm{Cl}^{-}$-deficient solution instead of increasing considerably, as observed. Also the resting chloride conductance in the neurons of Aplysia may be too low (Ascher et al., 1976) for a decrease in $\mathrm{Cl}^{-}$conductance to produce the FMRFamide-induced inward current. If a $\mathrm{Cl}^{-}$conductance in R14 were increased by FMRFamide in conjunction with a $\mathrm{Na}^{+}$-conductance increase, the FMRFamide-induced slow inward current would increase with decreasing [ $\left.\mathrm{Cl}^{-}\right]$because of the reduced offsetting of the inward current by the $\mathrm{Cl}^{-}$outward current. Reduction of such an effect by decreasing $\mathrm{Cl}^{-}$would enhance the net inward current, as observed. However, if this were occurring, the response to FMRFamide should be hyperpolarizing at low $\left[\mathrm{Na}^{+}\right]$, which was not the case. Thus, the origin of the effect of $\mathrm{Cl}^{-}$remains to be clarified.

The NSR region of R14 is shifted to substantially higher voltages but is not blocked by $\mathrm{Ba}^{21}$ and divalent ion $\mathrm{Ca}^{21}$-channel blockers (Fig. 11). Therefore, $\mathrm{Ca}^{2+}$ probably does not contribute substantially to the negative resistance region in R14. Analogous behavior has been characterized in muscle fibers by Hahin and Campbell (1983); they concluded that divalent cations shifted the NSR region by binding to specific sites on the membrane surface and changing the potential sensed by the gating particle.

The FMRFamide-induced inward current depends inversely on the $\mathrm{Ca}^{2+}$ concentration. At $-50 \mathrm{mV}$, this response was strongly blocked by high concentrations of $\mathrm{Ni}^{2+}$ and $\mathrm{Ba}^{2+}$. However, $\mathrm{Co}^{2+}$ and $\mathrm{Ni}^{2+}$ were ineffective at concentrations that ordinarily block $\mathrm{Ca}^{2+}$ channels, at least in Helix neurons (Akaike et al., 1978). This suggests that at high concentrations those ions might act on $\mathrm{R} 14$ by mechanisms other than directly blocking $\mathrm{Ca}^{2+}$ channels, possibly in the same way as does increasing $\left[\mathrm{Ca}^{2+}\right.$. Reduction of the FMRFamide response in the presence of 50 $\mathrm{mM} \mathrm{Ni}{ }^{2+}$ at $-50 \mathrm{mV}$ could be due to a shift of the voltage dependence of the response analogous to the shift of the normal $I-V$ relationship by $50 \mathrm{~mm} \mathrm{Ni}^{2+}$ (Fig. $11 B$ ). Thus, $\mathrm{Ca}^{2+}$ may act on the FMRFamide response by a mechanism analogous to that suggested by Hahin and Campbell (1983). The voltage-dependent block of the $\mathrm{Na}^{+}$channel by $\mathrm{Ca}^{2+}$ in nerve fiber of frog is thought to occur by $\mathrm{Ca}^{2+}$ entering the open $\mathrm{Na}^{+}$channel and binding there, preventing $\mathrm{Na}^{+}$passage (Woodhull, 1973). This is another possible mechanism for the effect of $\left[\mathrm{Ca}^{2+}\right]$.

The effects of $\left[\mathrm{Ca}^{2+}\right]$ may play a role in determining the response of R14 to FMRFamide under physiological circumstances, as $\mathrm{Ca}^{2+}$ ions would leave external binding sites upon depolarization. This could affect the potential sensed by the gating particle (Hahin and Campbell, 1983) or affect the channel protein conformations in other ways. However, this speculation is in need of investigation. Involvements of divalent cations in the voltage dependencies of other channels have recently been established (Mayer et al., 1984; Nowak et al., 1984; Matsuda et al., 1987).

Induction or enhancement of NSR regions of Aplysia neurons 


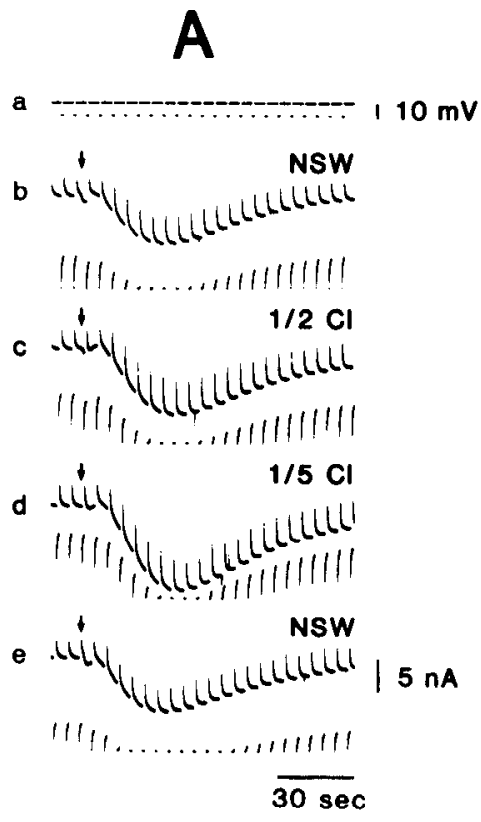

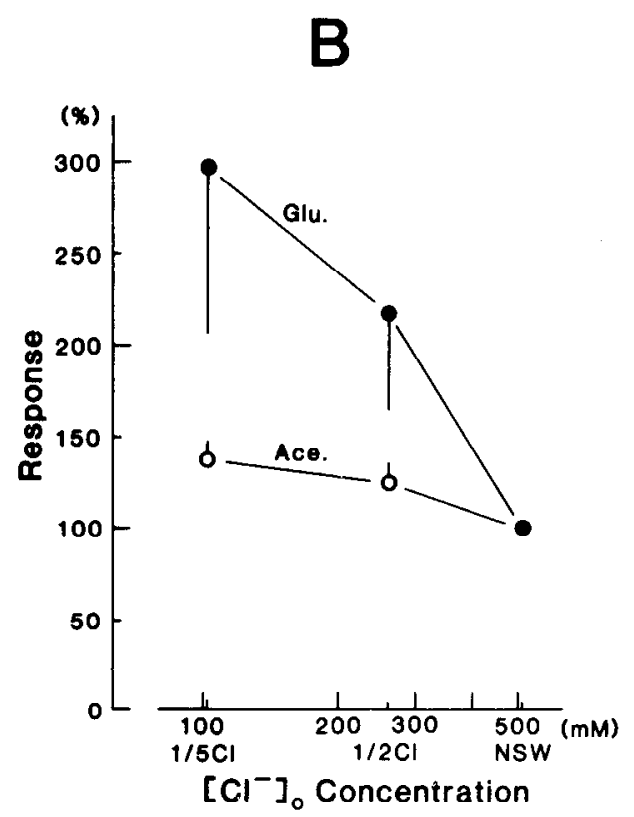

Figure 13. Dependence of the FMRFamide response on external $\left[\mathrm{Cl}^{-}\right]$. $A, a$, Voltage monitor during voltage clamp; $b$, control response in normal seawater; $c$, after 8 min of perfusing with $0.5 \times\left[\mathrm{Cl}^{-}\right] ; d$, after 8 min of perfusing with $0.2 \times\left[\mathrm{Cl}^{-}\right] ; e$, after $8 \mathrm{~min}$ washout with normal seawater. $\mathrm{Cl}^{-}$was replaced with acetate. $B$, Mean $( \pm \mathrm{SE})$ of 3 experiments using different preparations. When $\mathrm{Cl}^{-}$was substituted by acetate, the FMRFamide response (open circles) increased to $125 \pm 11 \%$ in $0.5 \times\left[\mathrm{Cl}^{-}\right]$ and to $137 \pm 11 \%$ in $0.2 \times\left[\mathrm{Cl}^{-}\right]$solution. When $\mathrm{Cl}^{-}$was replaced with gluconate ion, the FMRFamide response (closed circles) was markedly enhanced to $219 \pm 54 \%$ in $0.5 \times\left[\mathrm{Cl}^{-}\right]$seawater and to $297 \pm 91 \%$ in $0.2 \times\left[\mathrm{Cl}^{-}\right]$. by peptides other than FMRFamide has been reported. This affects the firing patterns of the neurons. In vivo $\mathrm{R} 14$ can be silent (the usual situation observed here), but it can burst (Rittenhouse and Price, 1986a). FMRFamide causes unclamped R14 to fire. The shift of the $I-V$ relationship of $\mathrm{R} 14$ by FMRFamide would affect the firing pattern of the neuron. Lysine vasopressin alters the $I-V$ curve for Otala lactea neuron 11 from an all-positive slope to an N-shaped curve (Barker and Smith, 1976). Kirk and Scheller (1986) showed that Aplysia egglaying peptide enhanced the NSR region of the $I-V$ curve in Aplysia neuron B16 and that this enhancement was caused by a voltage-dependent $\mathrm{Na}^{+}$-inward current. The present work adds to indications that induction or modification of NSR regions of $I-V$ curves is a widespread mechanism of action of peptides on neurons.

The responses to FMRFamide were not due to indirect synaptic effects because R14 has very little synaptic input (Coggeshall et al., 1966), because FMRFamide was applied directly to the soma membrane of R14, not to the neuropil, and because TTX, which would hlock action potentials in presynaptic terminals, had little effect. For these reasons, it is also unlikely that endogenous effects of FMRFamide on R14, if any, are synaptically mediated. Hence the responses characterized here may be a mechanism of action of humoral factors. R14 is inhibited by firing of the peptidergic bag cells (Mayeri et al., 1979), an effect that is almost certainly mediated by release of a peptide or peptides into the body fluid rather than at synapses.

Considerable evidence points to a role of R14 in the modulation of the control of the Aplysia's circulatory system (Price and McAdoo, 1979; Price et al., 1984; Sawada et al., 1984; Rittenhouse and Price, 1986a, b). Thus, it is possible that the sensitivity of the responses of R14 to external ions, chemical messengers, and amino acids (Ichinose and McAdoo, 1985; Ichinose ct al., 1985) arc means whereby R14 senses and responds to the state of the organism and participates in the control thereof. Rittenhouse and Price (1986b) have suggested that R14 and the closely related neurons R3-R13 may be involved in the control of homeostasis.
The similarity between the response of R14 to FMRFamide and those of other molluscan neurons to intracellular cAMP injections (Connor and Hochberger, 1984; Hara et al., 1985) suggests possible involvement of a second messenger. We will present evidence elsewhere that this messenger is not cAMP and that cGMP is a strong candidate (Ichinose and McAdoo, 1988). The response of R14 to FMRFamide is both chemically induced and voltage sensitive. Study of the dependencies of responses such as that of R14 to FMRFamide may help define how some channels achieve sensitivity to both membrane potential and neurochemical messengers.

\section{References}

Akaike, N., K. S. Lee, and A. M. Brown (1978) The calcium current of Helix neuron. J. Gen. Physiol. 71: 509-531.

Aldenhoff, J. B., G. Hofmeier, H. D. Lux, and D. Swandulla (1983) Stimulation of a sodium influx by cAMP in Helix neurons. Brain Res. 276: 289-296.

Ascher, P., D. Kunze, and T. O. Neild (1976) Chloride distribution in Aplysia neurones. J. Physiol. (Lond.) 256: 441-464.

Austin, T., S. Weiss, and K. Lukowiak (1983) FMRFamide effects on spontaneous and induced contractions of the anterior gizzard in $A p l y$ sia. Can. J. Physiol. Pharmacol. 61: 949-953.

Barker, J. L., and T. G. Smith (1976) Peptide regulation of neuronal membrane properties. Brain Res. 103: 167-170.

Belardetli, F., E. R. Kandel, and S. A. Siegelbaum (1987) Neuronal inhibition by the peptide FMRFamide involves opening of S- $\mathrm{K}^{+}$channels. Nature 325: 153-156.

Boyd, P. J., and R. J. Walker (1985) Actions of the molluscan neuropeptide FMRF-amide on neurones in the sub oesophageal ganglia of the snail Helix aspersa. Comp. Biochem. Physiol. 81C: 379-386.

Brezina, V., R. Eckert, and C. Erxleben (1987a) Modulation of potassium conductances by an endogenous neuropeptide in neurones of Aplysia californica. J. Physiol. (Lond.) 382: 267-290.

Brezina, V., R. Eckert, and C. Erxleben (1987b) Suppression of calcium current by an endogenous neuropeptide in neurons of Aplysia californica. J. Physiol. (Lond.) 388: 565.

Brown, R. O., D. Gusman, A. I. Basbaum, and E. Mayeri (1985) Identification of Aplysia neurons containing immunoreactive FMRFamide. Neuropeptides 6: 517-520.

Coggeshall, R. E., E. R. Kandel, I. Kupfermann, and R. Waziri (1966) A morphological and functional study on a cluster of identifiable 
neurosecretory cells in the abdominal ganglion of Aplysia californica. J. Cell Biol. 31: 363-368.

Colombaioni, L., D. Paupardin-Tritsch, P. P. Vidal, and H. M. Gerschenfeld (1985) The neuropeptide FMRFamide decreases both the $\mathrm{Ca}^{++}$conductance and a cyclic $3^{\prime}, 5^{\prime}$-adenosine monophosphate-dependent $\mathrm{K}^{+}$conductance in identified molluscan neurons. J. Neurosci. 5: 2533-2538.

Connor, J. A., and P. Hockberger (1984) A novel membrane sodium current induced by injection of cyclic nucleotides into gastropod neurones. 354: 139-162.

Cottrell, G. A. (1982) FMRFamide neuropeptides simultaneously increase and decrease $\mathrm{K}^{+}$currents in an identified neurone. Nature 296: 87-89.

Cottrell, G. A., N. W. Davies, and K. A. Green (1984) Multiple actions of a molluscan cardioexcitatory neuropeptide and related peptides on identified Helix neurones. J. Physiol. (Lond.) 356: 315-333.

Frazier, W. T., F. R. Kandel, I. Kupfermann, R. Waziri, and R. F. Coggeshall (1967) Morphological and functional properties of identified neurons in the abdominal ganglion of Aplysia californica. J. Neurophysiol. 30: 1288-1351.

Greenberg, M. J., S. D. Painter, K. E. Doble, G. T. Nagle, D. A. Price, and H. K. Lehman (1983) The molluscan neurosecretory peptide FMRFamide: Comparative pharmacology and relationship to the enkephalins. Fed. Proc. 42: 82-86.

Hahin, R., and D. T. Campbell (1983) Simple shifts in the voltage dependence of sodium channel gating caused by divalent cations. J. Gen. Physiol. 82: 785-805.

Hara, N., M. Sawada, and T. Maeno (1985) Influences of pressureinjected cyclic AMP on the membrane current and characteristics of an identified neuron of Aplysia kurodai. Jpn. J. Physiol. 35: 9851012 .

Ichinose, M., and D. J. McAdoo (1985) Excitatory effect of amino acids on identified neuron R14 of Aplysia. II. Neutral amino acids and structure-activity relationships. J. Neurosci. Res. 14: 145-158.

Ichinose, M., and D. J. McAdoo (1986) The response of FMRFamide on R14 of the Aplysia abdominal ganglion. Soc. Neurosci. Abstr. 12: 149.

Ichinose, M., and D. J. McAdoo (1988) The cyclic GMP-induced inward current in neuron R14 of Aplysia californica: Similarity to the FMRFamide-induced inward current. J. Neurobiol. (in press).

Ichinose, M., M. Sawada, and T. Maeno (1985) Excitatory effects of amino acids on identified neuron R14 of Aplysia. I. Glycine-induced depolarization and its ionic mechanism. J. Neurosci. Res. 14: 129143.

Kirk, M. D., and R. H. Scheller (1986) Egg-laying hormone of Aplysia induces a voltage-dependent slow inward current carried by $\mathrm{Na}^{+}$in an identified motoneuron. Proc. Natl. Acad. Sci. USA 83: 3017-3021.

Kononenko, N. I., P. G. Kostyuk, and A. D. Scherbatko (1983) The effect of intracellular cAMP injections on stationary membrane conductance and voltage- and time-dependent ionic currents in identified snail neurons. Brain Res. 268: 321-328.

Krieger, D. T., M. J. Brownstein, and J. B. Martin (1983) Brain Peptides, Wiley, New York.

Kunze, D. L., and A. M. Brown (1971) Internal potassium and chloride activities and the effects of acetylcholine on identifiable Aplysia neurones. Nature [New Biol.] 229: 229-231.

Lloyd, P. E. (1986) The small cardioactive peptides: A class of modulatory neuropeptides in Aplysia. Trends Neurosci. 9: 428-432.
Matsuda, H., A. Saigawa, and H. Irisawa (1987) Ohmic conductance through the inwardly rectifying $\mathrm{K}$ channel and blocking by internal $\mathrm{Mg}^{2+}$. Nature 325: 156-159.

Mayer, M. L., G. L. Westbrook, and P. B. Guthrie (1984) Voltagedependent block by $\mathrm{Mg}^{2+}$ of NMDA responses in spinal cord neurones. Nature 309: 261-263.

Mayeri, E., P. Brownell, and W. D. Branton (1979) Multiple, prolonged actions of neuroendocrine bag cells on neurons in Aplysia. II. Effects on beating pacemaker and silent neurons. J. Neurophysiol. 42:11851197.

Nowak, L., P. Bregestovski, P. Ascher, A. Herbert, and A. Prochiantz. (1984) Magnesium gates glutamate-activated channels in mouse central neurones. Nature 307: 462-465.

Price, D. A., and M. J. Greenberg (1977) Purification and characterization of a cardioexcitatory neuropeptide from the central ganglia of a bivalve mollusc. Prep. Biochem. 7: 261-281.

Price, C. H., and D J. McAdoo (1979) Anatomy and ultrastructure of the axons and terminals of neurons R3-R14 in Aplysia. J. Comp. Neurol. 188: 647-677.

Price, C. H., W. Fowle, and A. R. Rittenhouse (1984) Anatomy and innervation of the anterior aorta of Aplysia and the ultrastructure of specialized neuromuscular junctions on vascular smooth muscle. J. Comp. Neurol. 222: 366-382.

Richmond, J. E., A. G. M. Bullock, and K. Lukowiak (1986) Peptidergic modulation of a neuromuscular junction in Aplysia bioactivity and immunocytochemistry. Brain Res. 370: 159-164.

Rittenhouse, A. R., and C. H. Price (1986a) Anatomical and electrophysiological study of multitransmitter neuron R14 of Aplysia. J. Comp. Neurol. 247: 447-456.

Rittenhouse, A. R., and C. H. Price (1986b) Electrophysiological and anatomical identification of the peripheral axons and target tissues of Aplysia neurons R3-14 and their status as multifunctional, multimessenger neurons. J. Neurosci. 6: 2071-2084.

Rothman, B. S., K. A. Sigvardt, D. H. Hawke, R. O. Brown, J. E. Shively, and E. Mayeri (1985) Identification and primary structural analysis of peptide II, an end-product of precursor processing in cells R3-R14 of Aplysia. Peptides 6: 1113-1118.

Ruben, P., J. W. Johnson, and S. Thompson (1986) Analysis of FMRFamide effects on Aplysia bursting neurons. J. Neurosci. 6: 252-259.

Sawada, M., D. J. McAdoo, M. Ichinose, and C. H. Price (1984) Influences of glycine and neuron R14 on contraction of the anterior aorta of Aplysia. Jpn. J. Physiol. 34: 747-767.

Scheller, R. H., J. F. Jackson, L. B. McAllister, B. S. Rothman, E Mayeri, and R. Axel (1983) A single gene encodes multiple neuropeptides mediating a stereotyped behavior. Cell 32: 7-22.

Stone, L. S., and E. Mayeri (1981) Multiple actions of FMRFamide on identified neurons in the abdominal ganglion of Aplysia. Soc. Neurosci. Abstr. 7: 636

Weiss, S., J. I. Goldberg, K. S. Chohan, W. K. Stell, G. I. Drummond, and K. Lukowiak (1984) Evidence for FMRFamide as a neurotransmitter in the gill of Aplysia californica. J. Neurosci. 4: 1994-2000.

Willis, J. A., G. L. Gaubatz, and D. O. Carpenter (1974) The role of the electrogenic sodium pump in modulation of pacemaker discharge of Aplysia neurons. J. Cell. Physiol. 84: 463.

Woodhull, A. M. (1973) Ionic blockage of sodium channels in nerve. J. Gen. Physiol. 61: 687-708. 